\title{
THE EFFECT OF COLD WATER IMMERSION ON PAIN, MUSCLE RECRUITMENT AND POSTURAL CONTROL IN ATHLETES
}

\author{
EFEITO DA IMERSÃO EM ÁGUA FRIA SOBREDOR, RECRUTAMENTO MUSCULARE CONTROLEPOSTURAL \\ EMATLETAS
}

\begin{abstract}
EFECTO DE LA INMERSIÓN EN AGUA FRÍA SOBRE EL DOLOR, EL RECLUTAMIENTO MUSCULAR Y CONTROL POSTURAL EN ATLETAS
\end{abstract}

\begin{abstract}
Fernanda Bortolo Pesenti ${ }^{1,2}$ (DD (Physiotherapist)

Rubens Alexandre da Silva1,3,4 (D) (Physiotherapist)

Daniel Correa Monteiro² (ID)

(Physiotherapist)

Leticia Alves da Silva² (ID

(Physiotherapist)

Christiane de Souza Guerino (D) Macedo 1,2

(Physiotherapist)

\section{Universidade Estadual de Londrina (UEL), Master and Doctoral Programs in Rehabilitation Sciences (UNOPAR), Londrina, Paraná, Brazil. \\ 2. Universidade Estadual de \\ Londrina (UEL), Laboratory \\ Teaching, Research and Extension in Sports Physiotherapy (LAFESP), Londrina, PR, Brazil. \\ 3. I'université McGill, Département des Sciences de la Santé, \\ Programme de Physiothérapie Saguenay, offert en extension, à I'UQAC, Saguenay, Québec, Canada. \\ 4. Universidade Norte do Paraná (UNOPAR), Center for Health Science Research, Laboratory of Functional Evaluation and Human Motor Performance (LAFUP), Londrina, Paraná, Brazil.}

\section{Correspondence: \\ Christiane de Souza Guerino Macedo \\ Universidade Estadual de Londrina Av. Robert Koch, 60, Operária, Londrina, PR, Brazil. 86038-350. fernanda_pesenti@hotmail.com}

\begin{abstract}
Introduction: Numerous recovery strategies have been used to minimize performance loss related to delayed onset muscle soreness in athletes, and are part of prevention programs and training of most high-level sports. Objective: To analyze the effects of cold-water immersion on delayed-onset muscle soreness, muscle recruitment, and postural control in soccer players. Objective: The maximum load of the quadriceps femoris muscle strength was determined. After three days, the pain scale was used to measure the subject's pain intensity. The recruitment of the quadriceps muscle was determined at the moment of the kick, and was associated with postural control. Methods: Randomized, blinded clinical trial study. Two repeated series of maximum load sets at $60 \%$ MVC, performed in a knee extension chair, were used to induce quadriceps fatigue in the athletes. Participants: Twenty-eight soccer players were allocated to four intervention groups: cold water immersion (CWIG, $n=7$ ), thermoneutral water immersion (TWIG, $n=7$ ), active recovery ( $A R G, n=7)$, and rest $(R G, n=7)$, with each intervention being carried out for ten minutes. Revaluations were carried out after 24, 48, and 72 hours of the fatigue protocol. Results: Pain intensity in the CWIG returned to baseline after 72 hours, while the TWIG, ARG, and RG continued to feel greater pain. For the other outcomes, no differences were found between the groups. Conclusion: With regard to muscle recruitment and postural control at the time of the kick, no significant differences were found for the time periods or intervention established. Level of evidence l; High-quality randomized clinical trial with or without statistically significant difference, but with narrow confidence intervals.
\end{abstract}

Keywords: Postural control; Electromyography; Soccer.

\section{RESUMO}

Introdução: Numerosas estratégias de recuperação têm sido usadas para minimizar a perda de desempenho decorrente de dor muscular de início tardio em atletas e fazem parte de programas de prevenção e treinamento da maioria dos esportes de alto nível. Objetivos: Analisar os efeitos da imersão em água fria sobre a dor muscular tardia, o recrutamento muscular e o controle postural de jogadores de futebol. Métodos: Estudo clínico randomizado e cego. Determinou-se a carga máxima da força muscular do quadríceps femoral. Depois de três dias, empregou-se a escala de dor para avaliar a intensidade da dor dos indivíduos. O recrutamento do quadríceps femoral foi determinado no momento do chute e associado ao controle postural. Duas séries repetidas de conjuntos de carga máxima a $60 \%$ da CVM, realizadas em uma cadeira extensora de joelho, foram usadas para induzir fadiga do quadríceps nos atletas. Vinte e oito jogadores de futebol foram randomizados em quatro grupos de intervenção: imersão em água fria $(G I A F, n=7)$, imersão em água termoneutra $(G I A T, n=7)$, recuperação ativa $(G R A, n=7)$ e repouso $(G R, n=7)$, sendo cada intervenção realizada por dez minutos. As reavaliações ocorreram depois de 24, 48 e 72 horas do protocolo de fadiga. Resultados: A intensidade da dor no GIAFvoltou para o valor basal após 72 horas, enquanto GIAT, GRA e GR continuaram a sentir dor acentuada. Não foram encontradas diferenças entre os grupos com relação aos outros desfechos. Conclusão: Com relação ao recrutamento muscular e ao controle postural no momento do chute, não foram encontradas diferenças significativas para os períodos ou intervenções estabelecidas. Nível de evidência l; Estudo clínico randomizado de alta qualidade com ou sem diferença estatisticamente significante, mas com intervalos de confiança estreitos.

\section{Descritores: Controle postural; Eletromiografia; Futebol.}

\section{RESUMEN}

Introducción: Se han utilizado numerosas estrategias de recuperación para minimizar la pérdida de rendimiento relacionada con el dolor muscular de aparición tardía en los atletas y son parte de programas de prevención y entrenamiento de la mayoría de los deportes de alto nivel. Objetivos: Analizar los efectos de la inmersión en agua fría sobre el dolor muscular tardío, el reclutamiento muscular y el control postural en jugadores de fútbol. Métodos: Estudio clínico aleatorizado y ciego. Se determinó la carga máxima de la fuerza muscular del cuádriceps femoral. Después de tres días, se usó la escala de dolor para evaluar la intensidad del dolor de los individuos. El reclutamiento del cuádriceps femoral se determinó en el momento de la patada y se asoció con el control postural. Se utilizaron dos series repetidas de conjuntos de carga máxima al 60\% de la CVM en una silla de extensión de rodilla para inducir fatiga del cuádriceps en atletas. Veintiocho jugadores de fútbol fueron asignados al azar en cuatro grupos de intervención: inmersión en agua 
fría (GIAF, $n=7)$, inmersión en agua termoneutra (GIAT, $n=7)$, recuperación activa ( $R A, n=7)$ y descanso $(G D, n=7)$, con cada intervención realizada durante diez minutos. Las reevaluaciones ocurrieron después de 24, 48 y 72 horas después del protocolo de fatiga. Las revaluaciones ocurrieron después de 24, 48 y 72 horas del protocolo de fatiga. Resultados: La intensidad del dolor en el GIAF volvió a la línea de base después de 72 horas, mientras que GIAT, GRA y GD continuaron experimentando dolor intenso. No seencontraron diferencias entre los grupos con respecto a otros resultados. Conclusión: Con respecto al reclutamiento musculary el control postural en el momento de la patada, no se encontraron diferencias significativas para los períodos o la intervención establecida. Nivel de evidencia l; Ensayo clínico aleatorizado de alta calidad con o sin una diferencia estadísticamente significativa, pero con intervalos de confianza estrechos.

\section{Descriptores: Control postural; Electromiografía; Fútbol.}

\section{INTRODUCTION}

Inumerous recovery strategies have been used to minimize performance loss related to delayed onset muscle soreness (DOMS) in athletes. An appropriate recovery allows better physiological and psychological functioning, minimizes the effects of fatigue and helps athletes to achieve their best performance. ${ }^{1}$

Different recovery techniques utilised by athletes include, massage, active exercises, contrast baths, and cold water immersion. Cold water immersion (CWI) is currently one of the most popular interventional strategies used after exercise and can be easily performed in different situations ${ }^{2,3}$ to maintain physical performance, reduce DOMS and help recover muscle damage after repetitive high-level training and competition. ${ }^{4}$

There have been a number of systematic reviews, clinical trials, and meta-analysis in recent years on the use of recovery modalities within elite adult sport. ${ }^{5}$ Some studies have compared the effects of CWI with other techniques to reduce muscle soreness, such as active recovery, rest, and thermoneutral water immersion., ${ }^{2,6-9}$ However, no data currently exist to support this notion..$^{10}$ Clear results have not been observed with regard to sports gestures or the effect of CWI on the sports biomechanical variables. ${ }^{11}$ There are gaps in the knowledge and literature_which need to be filled by conducting further research on the topic. Thus, the present study focused on, comparing the effects of cold water immersion, active recovery, thermoneutral water immersion and rest on DOMS, muscle recruitment, and dynamic postural control in soccer players at the exact moment of the kick.

\section{METHODS}

This was a randomized, blinded study in the area of physical performance, postural control, and sports biomechanics. The research was approved by the Research Ethics Committee of the institution (case N. 1.700.748) and registered on www.clinicaltrials.org (ID NCT02806609).

The sample size and power were calculated using Power and Sample Size Software, with a 95\% confidence interval, 5\% alpha, and 90\% power, considering the raw data (mean \pm SD) of the DOMS in the study, "Comparison of ice massage versus cold-water immersion on muscle damage and DOMS levels of elite wrestlers" where it presented 6,10 and 8,20 as means, 0,29 of standard deviation and $p=0,001$. Determining the ideal sample composed of two subjects in each group, but, the sample was composed of seven subjects per group, a total of 28 individuals.

Twenty-eight male soccer players, between the ages of 16 and 19, training five times a week, participated in this study. Players without complaints of musculoskeletal pain or a history of muscle injuries in the previous six months, hired by the same club, with the same training and competition intensity were included in the study. Participants were excluded if they had a vascular disorder, allergy to cold, had undergone surgery in the lower limbs, or presented any cold or flu symptoms.

All study participants were allocated randomly to one of the four groups using a computer-generated random number table (www. randon.org) and sealed opaque envelope technique. Players opened the envelope to find out the intervention group to which they belonged: CWIG $(n=7)$, TWIG $(n=7)$, ARG $(n=7)$, and CG $(n=7)$.

A questionnaire was applied to gather anthropometric and physical performance information about the participants (age, height, body mass, category, position on the field, soccer training schedule, and history of injuries). The numerical scale of pain (NSP) was used to rate the current pain intensity, with scores ranging from 0 to 10 .

The exercise protocol was carried out on a leg extension chair (VOEIL ${ }^{\circledR}$ ) at the training location to gauge muscle strength using the one repetition maximum (1RM), and induce DOMS in the quadriceps muscle.

EMG data were collected using a 4-channel EMG system (EMG 430 C, EMG System ${ }^{\circledR}$ do Brasil Ltda). The EMG records were captured using three pre-amplified active electrodes and band-pass filtered between 25 and $450 \mathrm{~Hz}$, with a sampling rate of $2000 \mathrm{~Hz}$. After the EMG activity capture, the Root Mean Square (RMS) value of the EMG signal was used to determine the time of the event and set the mean of the RMS amplitude during the task for each muscle. The RMS values were calculated for the vastus medialis oblique (VMO), vastus lateralis (VL), and rectus femoris (RF) muscles in maximum isometric contraction. The mean activation level for the muscles was calculated and then normalized to obtain the percentage of recruitment/muscle contribution towards maximum voluntary isometric contraction (MVIC).

Postural stability was evaluated using a force platform (NS_BIO1470, EMG System do Brasil ${ }^{\circledR}$, SP Ltda.), with sampling frequency of $100 \mathrm{~Hz}$. The variables for the stability analysis during the kick movement were the total center of pressure (COP) oscillation area and the average velocity of the COP oscillation (VEL), in both the anterior-posterior (AP) and medio-lateral (ML) directions.

The collections were carried out at the team training center, on previously scheduled dates and times and by common agreement among researchers, players, and the team technical staff. The room temperature during data collection ranged from 28 and $30^{\circ} \mathrm{C}$.

The participants signed the informed consent form (ICF), answered the questionnaire for the characterization of the sample and rated their pain intensity on a scale of 0-10. Subsequently, each subject performed a 1 RM test of knee extension as proposed by the American College of Sports Medicine, ${ }^{11}$ for the analysis of maximum strength of the quadriceps muscle.

Three days later, the players returned to the same location and were asked to fill in the NSP again.

The electrodes were positioned on the lower muscles of the non-dominant leg ( $\mathrm{VMO}, \mathrm{VL}$, and RF, bilaterally) parallel to the direction of the muscle fibers, with a $1 \mathrm{~cm}$ distance between them, according to the recommendations for Surface EMG for Non-invasive Assessment of Muscles.

The athlete sat on the leg extension apparatus with the knee flexed at $90^{\circ}$, upper limbs alongside the body, and hands holding the side bar insulated with rubber to prevent interference and noise while recording 
EMG signals. Following the knee flexion exercise, subjects were asked to perform three sustained maximal isometric voluntary contractions of knee extension for eight seconds, with a rest interval of one minute.

The collection of PC data was performed with the individual standing in the indicated position (non-dominant lower limb -NDLL) on the platform. (Figure 1) A ball was thrown to the participant, who was required to kick it as far as possible with the DLL. Three kicks were performed to acquire electromyographic and postural control data. Data collection for each kick took five seconds. The mean values obtained from the three data collections were used for the analysis. Between each kick, the athlete sat comfortably in a chair for a 30 second rest.

The electrodes were then removed and the athlete was submitted to the fatigue protocol in the quadriceps muscle. At this time, the player was instructed to perform a maximum knee extension twice with $60 \%$ of pre-training $1 \mathrm{RM}^{12}$ and a 30 second interval between attempts. Immediately after completing the fatigue protocol, the athlete was referred to one of the four intervention groups:

Cold water immersion - The participants remained in a bathtub (Cryo Control - Ice Bath Systems ${ }^{\circledR}$ ) with an attached filtration system and a continuous cooling machine, with constant water temperature at $10^{\circ} \mathrm{C}^{13}$ for 10 minutes. The water level was set to the iliac crest. ${ }^{14}$

Water immersion at room temperature - the athletes were submitted to the same water immersion protocol, however, the water was set at room temperature.

Active recovery - athletes used a treadmill for 10 minutes at a light and comfortable walking pace.

Control - The athletes were asked to remain seated and relax for 10 minutes in a comfortable chair.

Randomization and implementation of the protocols were carried out in separate rooms. The assessment was scored by blind raters to eliminate bias. Following the intervention protocol, the participants were instructed to maintain their sleep and diet routine, and refrain from any kind of training or physical activity.

The same protocol as for the three repetitions of the kick movement, which included EMG acquisition, postural control, and participants' pain rating (NSP) data, was performed three times at 24, 48 and 72 hour follow-up, after completion of the fatigue protocol.

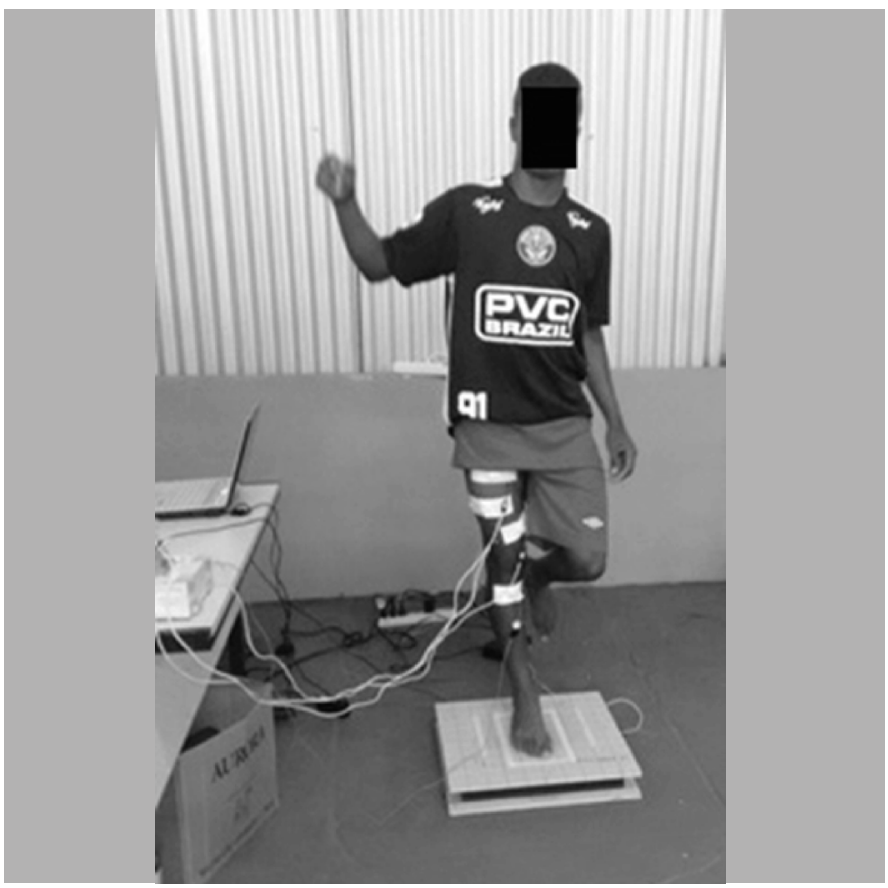

Figure 1. Athlete positioned on the non-dominant lower limb, waiting for the moment to kick.

\section{Statistical analysis}

The results were based on the following variables: pain intensity in the quadriceps muscle; analysis of muscle recruitment (normalized by $\mathrm{MVIC}$ ) of the $\mathrm{VMO}$, and the RF muscles at the time of the kick; postural control at the time of the kick, considering the center of pressure (COP) oscillation area and velocity of the COP oscillation (VEL), in both the anterior-posterior (AP) and medio-lateral (ML) directions.

The Shapiro-Wilk test was used to check the normality of data. All variables were compared between the four groups at all four moments of analysis by the ANOVA test and Bonferroni post-hoc test. The Student's t test was used for comparison between initial and final periods of pain. Statistical analyses were performed using Statistical Package for Social Sciences, version 20 (SPSS Inc., Chicago, USA). The level of significance was set at $p \leq 0.05$.

\section{RESULTS}

There were no significant differences between the four groups with regards to age, weight, height, time of practice, training days, or matches, as shown in Table 1.

There were no statistically significant differences between groups for muscle recruitment or postural control. For the DOMS analysis, intra-group comparisons, the values were significantly higher at 24 and/ or 48 hour follow-up, for all intervention groups, which confirmed the effectiveness of the DOMS protocol, as shown in Tables 2, 3, 4, and 5.

Table 1. Anthropometric and physical performance characteristics of soccer players

\begin{tabular}{c|c|c|c|c|c}
\hline & $\begin{array}{c}\text { Cold water } \\
\text { immersion }\end{array}$ & $\begin{array}{c}\text { Thermoneutral } \\
\text { water } \\
\text { immersion }\end{array}$ & $\begin{array}{c}\text { Active } \\
\text { recovery }\end{array}$ & Rest & ANOVA \\
\hline Age (years) & $16.5 \pm 0.9$ & $16.8 \pm 0.8$ & $16.2 \pm 0.4$ & $17.2 \pm 0.9$ & 0.183 \\
\hline Weight (Kg) & $69.7 \pm 5.1$ & $73.4 \pm 7.4$ & $64.2 \pm 4.4$ & $72.2 \pm 7.4$ & 0.063 \\
\hline Height (m) & $174 \pm 5.2$ & $178 \pm 6.4$ & $172 \pm 2.9$ & $179 \pm 5$ & 0.076 \\
\hline Time of practice (years) & $9.2 \pm 1.7$ & $8.1 \pm 2.6$ & $8.7 \pm 1.9$ & $6.7 \pm 2.2$ & 0.184 \\
\hline Training/week & $5 \pm 0$ & $5 \pm 0$ & $5 \pm 0$ & $5 \pm 0$ & 1 \\
\hline Matches/week & $1 \pm 0$ & $1 \pm 0$ & $1 \pm 0$ & $1 \pm 0$ & 0.141 \\
\hline Anova test values are mean \pm SD & & & & &
\end{tabular}

Table 2. Results obtained for the cold water immersion group.

\begin{tabular}{|c|c|c|c|c|c|}
\hline \multirow[t]{2}{*}{ Variables } & \multicolumn{4}{|c|}{ Time periods of analyses } & \multirow[t]{2}{*}{ ANOVA } \\
\hline & Pre & $\begin{array}{l}24 \text { hour } \\
\text { follow-up }\end{array}$ & $\begin{array}{l}48 \text { hour } \\
\text { follow-up }\end{array}$ & $\begin{array}{l}72 \text { hour } \\
\text { follow-up }\end{array}$ & \\
\hline PAIN & 0 & $3.7^{*} \pm 1.7$ & $3.2^{*} \pm 2.21$ & $1.5 \pm 2.57$ & 0.005 \\
\hline $\mathrm{COP}$ & $62.1 \pm 31.6$ & $47.8 \pm 20$ & $32.1 \pm 13.02$ & $43.5 \pm 13.01$ & 0.328 \\
\hline VEL AP & $11.96 \pm 3.8$ & $10.35 \pm 2.62$ & $9.11 \pm 1.62$ & $8.90 \pm 1.52$ & 0.126 \\
\hline VEL ML & $7.98 \pm 1.91$ & $6.97 \pm 1.47$ & $7.47 \pm 1.09$ & $6.54 \pm 1.45$ & 0.337 \\
\hline RMS RF (\%MVIC) & $22.73 \pm 4.61$ & $22.82 \pm 3.73$ & $21.94 \pm 5.3$ & $22.12 \pm 6.52$ & 1 \\
\hline RMS VL (\%MVIC) & $28.61 \pm 9.63$ & $28.88 \pm 9.9$ & $27.32 \pm 11.05$ & $26.16 \pm 10.15$ & 1 \\
\hline RMS VM (\%MVIC) & $28.23 \pm 8.99$ & $27.61 \pm 10.1$ & $30.54 \pm 13.27$ & $26.52 \pm 13.27$ & 1 \\
\hline
\end{tabular}

* Statistically significant difference found for pain through ANOVA and Bonferroni post-hoc test compared with the pre-intervention period. Values are mean \pm SD.

Table 3. Results obtained for the thermoneutral water immersion group.

\begin{tabular}{c|c|c|c|c|c}
\hline Variables & \multicolumn{4}{|c|}{ Time periods of analyses } & ANOVA \\
\hline & Pre & $\begin{array}{c}\text { 24 hour } \\
\text { follow-up }\end{array}$ & $\begin{array}{c}\mathbf{4 8} \text { hour } \\
\text { follow-up }\end{array}$ & $\begin{array}{c}\mathbf{7 2} \text { hour } \\
\text { follow-up }\end{array}$ & \\
\hline PAIN & $0.72 \pm 1.25$ & $5.42^{*} \pm 0.97$ & $6.14^{*} \pm 2.19$ & $3.14 \pm 1.35$ & 0.000 \\
\hline COP & $68.61 \pm 28.47$ & $72.03 \pm 33.87$ & $42.42 \pm 15.33$ & $46.20 \pm 19.68$ & 0.084 \\
\hline VEL AP & $10.38 \pm 1.73$ & $10.79 \pm 2.27$ & $9.35 \pm 2.15$ & $9.39 \pm 2.56$ & 0.540 \\
\hline VEL ML & $7.83 \pm 1.66$ & $5.42 \pm 1.30$ & $7.12 \pm 1.37$ & $7.33 \pm 2.44$ & 0.745 \\
\hline RMS RF (\%MVIC) & $25.81 \pm 7.58$ & $27.76 \pm 9.23$ & $26.98 \pm 8.74$ & $33.02 \pm 20.04$ & 1 \\
\hline RMS VL (\%MVIC) & $33.86 \pm 9.42$ & $31.9 \pm 10.92$ & $31.61 \pm 11.73$ & $30.31 \pm 11.64$ & 1 \\
\hline RMS VM (\%MVIC) & $30.71 \pm 4.8$ & $31.32 \pm 9.66$ & $32.53 \pm 8.74$ & $30.15 \pm 8.82$ & 1 \\
\hline
\end{tabular}

* Statistically significant difference found for pain through ANOVA and Bonferroni post-hoc test compared with the pre-intervention period. Values are mean \pm SD 
The results showed that the DOMS of the soccer players reached peak intensity at different time periods (at 24 and 48 hours). Thus, a new approach to pain intensity was necessary, and therefore, three distinct time periods were established: baseline pain (pre fatigue), pain peak (highest value for pain between 24 and 48 hours) and final pain (after 72 hours). The values obtained via ANOVA showed that there were no significant differences between the four groups in the three time periods (pre-, pain peak, and after 72 hours) ( $p=0.06)$, thus, there were no difference in DOMS between the groups in the baseline moment $(p=0,33)$.

However, the comparison between the baseline and final pain intensity, using the Student's t-test, showed that only the CWIG returned to baseline pain, with no significant difference between these time periods $(p=0.39)$. In contrast, the TWIG ( $p=0.01), A R G(p=0.02)$, and $R G(p=0.02)$ did not return to the initial baseline pain intensity and showed significant differences. (Figure 2)

Table 4. Results obtained for the active recovery group.

\begin{tabular}{c|c|c|c|c|c}
\hline Variables & \multicolumn{4}{|c|}{ Time periods of analyses } & ANOVA \\
\hline & Pre & $\begin{array}{c}\mathbf{2 4} \text { hour } \\
\text { follow-up }\end{array}$ & $\begin{array}{c}\mathbf{4 8} \text { hour } \\
\text { follow-up }\end{array}$ & $\begin{array}{c}\mathbf{7 2} \text { hour } \\
\text { follow-up }\end{array}$ & \\
\hline PAIN & $0.14 \pm 0.37$ & $4.85^{*} \pm 1.95$ & $6^{*} \pm 2.08$ & $2.57 \pm 1.71$ & 0.000 \\
\hline COP & $39.88 \pm 13.36$ & $56.01 \pm 23.51$ & $62.93 \pm 48.87$ & $58.98 \pm 35.71$ & 0.597 \\
\hline VEL AP & $9.43 \pm 2.82$ & $9.74 \pm 1.91$ & $9.68 \pm 2.56$ & $9.94 \pm 2.53$ & 0.985 \\
\hline VEL ML & $6.63 \pm 1.26$ & $6.50 \pm 1.50$ & $6.56 \pm 1.06$ & $8.22 \pm 1.56$ & 0.076 \\
\hline RMS RF (\%MVIC) & $24.18 \pm 13.96$ & $24 \pm 14.12$ & $24.12 \pm 14.14$ & $24.16 \pm 14.43$ & 1 \\
\hline RMS VL (\%MVIC) & $32.24 \pm 10.11$ & $32.56 \pm 10.8$ & $31.91 \pm 10.15$ & $31.19 \pm 10.43$ & 1 \\
\hline RMS VM (\%MVIC) & $26.41 \pm 15.46$ & $27.59 \pm 15.98$ & $25.73 \pm 15.51$ & $25.67 \pm 16.58$ & 1 \\
\hline *Statistically significant difference found for pain through ANOVA and Bonferroni post-hoc test compared with \\
the pre-intervention period. Values are mean \pm SD.
\end{tabular}

Table 5. Results obtained for the rest group.

\begin{tabular}{c|c|c|c|c|c}
\hline Variables & \multicolumn{4}{|c|}{ Time periods of analyses } & ANOVA \\
\hline & Pre & $\begin{array}{c}\mathbf{2 4} \text { hour } \\
\text { follow-up }\end{array}$ & $\begin{array}{c}\mathbf{4 8} \text { hour } \\
\text { follow-up }\end{array}$ & $\begin{array}{c}\mathbf{7 2} \text { hour } \\
\text { follow-up }\end{array}$ & \\
\hline PAIN & $0.4 \pm 0.78$ & $5^{*} \pm 1.82$ & $5.1^{*} \pm 1.77$ & $2.5 \pm 1.51$ & 0.000 \\
\hline COP & $50.20 \pm 11.42$ & $51.98 \pm 12.95$ & $40.56 \pm 15.73$ & $32.99 \pm 11.05$ & 0.312 \\
\hline VEL AP & $9.71 \pm 0.99$ & $9.82^{*} \pm 0.82$ & $8.54 \pm 0.63^{*}$ & $8.99 \pm 0.69$ & 0.018 \\
\hline VEL ML & $6.94 \pm 0.9$ & $6.77 \pm 1.58$ & $6.85 \pm 1.21$ & $6.08 \pm 0.58$ & 0.484 \\
\hline RMS RF (\%MVIC) & $24.23 \pm 6.33$ & $24.94 \pm 6.49$ & $24.20 \pm 5.73$ & $24.4 \pm 6.3$ & 1 \\
\hline RMS VL (\%MVIC) & $35.06 \pm 10.03$ & $35.40 \pm 14.15$ & $34.50 \pm 12.30$ & $34.61 \pm 14.22$ & 1 \\
\hline RMS VM (\%MVIC) & $28.51 \pm 8.48$ & $29.36 \pm 11.18$ & $28.09 \pm 7.49$ & $26.65 \pm 7.81$ & 1 \\
\hline * Statistically significant difference found for pain through ANOVA and Bonferroni post-hoc test compared with \\
the pre-intervention period. Values are mean $+5 \mathrm{SD}$ & & &
\end{tabular}
the pre-intervention period. Values are mean \pm SD.

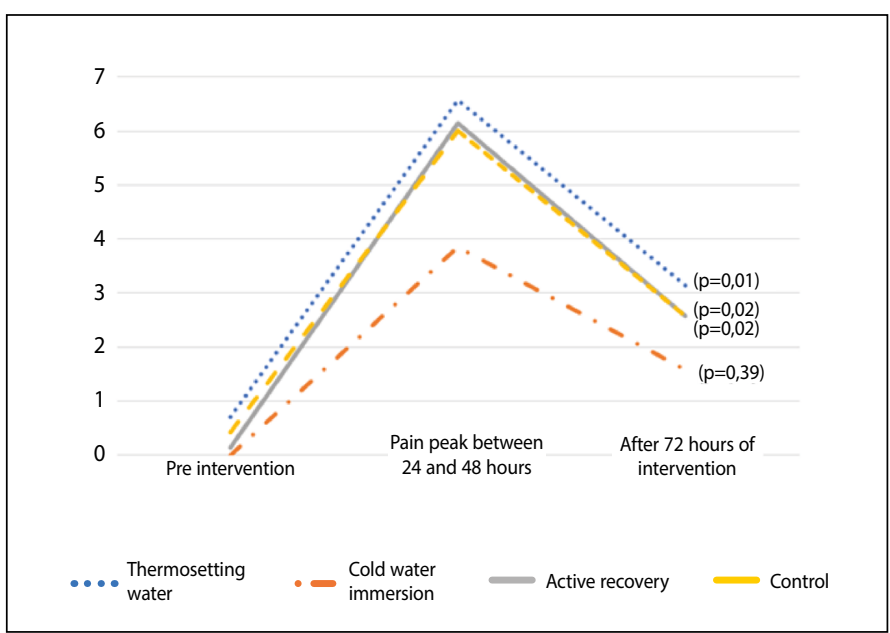

Figure 2. Analysis of pain intensity between different time periods: pre-intervention, pain peak at 24 or 48 hours, and after 72 hours. Results obtained by ANOVA.

\section{DISCUSSION}

The present study compared the interventions described in the literature for the recovery of DOMS in athletes: cold water immersion $(\mathrm{CWI})$, thermoneutral water immersion, active recovery, and rest ${ }^{15,16}$ and did not establish differences for postural control or muscle recruitment at the time of the kick after the interventions. The DOMS intensity increased significantly after the fatigue protocol and only the CWIG returned to the initial, pre-intervention values (without complaints of pain).

It is believed that the application of $\mathrm{CWI}$ at $10^{\circ} \mathrm{C}$ produces positive results in reducing DOMS. 16,17 In contrast, a recently published systematic review and meta-analysis showed that CWI with a water temperature between 11 and $15^{\circ} \mathrm{C}$ and an immersion time of 11-15 min can provide the best results. ${ }^{8}$ These aspects can be tested and compared in future studies, considering the fact that higher temperatures may be more pleasant to athletes. The water level was set to the iliac crest because pain was induced in the lower limbs only; therefore, there was no need for whole-body immersion. ${ }^{18}$

Immersion in thermoneutral water was used to determine how hydrostatic pressure affects recovery and not the water temperature, as reported in the studies of Broatch et al. ${ }_{1}^{19}$ or even the placebo effect of immersion. Active recovery was included in the present study since it is a common practice in sports as it clears the production and accumulation of blood lactate and may regulate the systemic circulation. Finally, we decided to establish a control group, whose participants were instructed only to relax.

The main focus of the present study was the DOMS, it is a commom symptoms in soccer players. The results showed that the induced DOMS protocol was effective, with significant increases for all groups within 24 or 48 hours. However, the fact that no significant differences were observed when the four intervention groups were compared was not expected. It was believed that, in light of the benefits already established by the literature and the decrease in skin temperature, the CWIG would achieve the best results regarding all the observed variables. On the other hand, the same group was the only one where athletes returned to baseline levels of pain intensity at 72 hours. Therefore, our results corroborate those found by Demirhan et al. ${ }^{20}$ that showed reduced DOMS with the application of cold water immersion in elite wrestlers.

In the present study, the evaluation of postural control was carried out by means of a force platform, considered the gold standard for this purpose. ${ }^{21}$ However, no significant differences were found between the groups, and the fatigue protocol had no impact on the postural control of the athletes evaluated, as observed by Tano et al..22

For the evaluation of the quadriceps muscle recruitment, the results showed no significant differences intra or between groups at the different time periods, as well as the results of Thain et al. ${ }^{23}$ performed immediately after the intervention, different from our study, which analyzed the effects of CWI immersion 72 hours after a DOMS-inducing protocol. Thus, the results of this study indicate that DOMS did not alter muscle recruitment at the time of kicking.

The results obtained regarding the effects of DOMS on postural control and muscle recruitment were based on the kick, and it is probable our evaluation protocol, which focused on a single biomechanical soccer movement (kicking), was not enough to interfere with the postural control of the player's support leg.

In conclusion, the group who underwent immerson in cold water $\left(10^{\circ} \mathrm{C}\right)$ up to the level of the iliac crest, for 10 minutes, was the only intervention for which DOMS returned to baseline, which confirmed the data reported in the literature. Although the DOMS inducing protocol did not alter postural control or muscle recruitment of the soccer players, future studies are necessary to determine the relationship between DOMS, postural control, muscle recruitment, and biomechanical performance. 


\section{CONCLUSION}

Finally, the fact that no significant differences were found between the interventions regarding the observed variables, including DOMS between groups, indicates that further studies should be carried out to develop new recovery strategies to produce clinically important reductions in DOMS and establish its real effects on the biomechanical variables among soccer players.

All authors declare no potential conflict of interest related to this article

AUTHORS' CONTRIBUTIONS: Each author made significant individual contributions to this manuscript. FBP: writing, data collection and statistical analysis; RAS: revision and interpretation of the results; DCM: and LAS: data collection; CSGM: writing, statistical analysis and revision. All the authors revised and approved the final version of the manuscript.

\section{REFERENCES}

1. Vaile J, Halson S, Graham S. Recovery review- science vs practice. J Aust Strength Cond. 2010;2:5-21.

2. Bleakley CM, Davison GW. What is the biochemical and physiological rationale for using cold-water immersion in sports recovery? A systematic review. Br J Sports Med. 2010;44(3):179-87.

3. 3. Ihsan M, Watson G, Abbiss CR. What are the physiological mechanisms for post-exercise cold water immersion in the recovery from prolonged endurance and intermittent exercise?. Sports Med. 2016;46(8):1095-109.

4. Costello JT, Culligan K, Selfe J, Donnelly AE. Muscle, skin and core temperature after- $110 \mathrm{C}$ cold air and 8C water treatment. PloS one. 2012; 7(11):e48190.

5. Macedo CS, Vicente RC, Cesário MD, Guirro RR. Cold-water immersion alters muscle recruitment and balance of basketball players during vertical jump landing. J sports sci. 2016;34(4):348-57.

6. Leeder J, Gissane C, van Someren K, Gregson W, Howatson G. Cold water immersion and recovery from strenuous exercise: a meta-analysis. Br J Sports Med. 2012;46(4):233-40.

7. Bieuzen F, Bleakley CM, Costello JT. Contrast water therapy and exercise induced muscle damage: a systematic review and meta-analysis. PLoS One. 2013;8(4):e62356.

8. Machado AF, Ferreira PH, Micheletti JK, de Almeida AC, Lemes IR, Vanderlei FM, et al. Can water temperature and immersion time influence the effect of cold water immersion on muscle soreness? A systematic review and meta-analysis. Sports Med. 2016;46(4):503-14.

9. Glasgow PD, Ferris R, Bleakley, CM. Cold water immersion in the management of delayed-onset muscle soreness: is dose important? A randomised controlled trial. Phys Ther Sport. 2014;15(4):228-33.

10. Peake J, Roberts L, Raastad T, Figueiredo V, Cameron-Smith D, Coombes J, et al. The effects of cold water immersion on inflammation, growth and neurotrophic factors in skeletal muscle after resistance exercise. FASEB J. 2016;30(1 Suppl):1291-4.

11. American College of Sports Medicine. ACSM's guidelines for exercise testing and prescription. 9 th ed. Philadelphia: Lippincott Williams \& Wilkins. 2013

12. Pereira MI, Gomes PS. Testes de força e resistência muscular: confiabilidade e predição de uma repetição máxima-revisão e novas evidências. Rev Bras Med Esporte. 2003;9(5):325-35.
13. Flouris AD, Friesen BJ, Carlson MJ, Casa DJ, Kenny GP. Effectiveness of cold water immersion for treating exertional heat stress when immediate response is not possible. Scand J Med Sci Sports. 2015;25(Suppl 1):229-39.

14. Ascensão A, Leite M, Rebelo AN, Magalhäes S, Magalhäes J. Effects of cold water immersion on the recovery of physical performance and muscle damage following a one-off soccer match. J Sports Sci. 2011; 29(3):217-25.

15. Bailey DM, Erith SJ, Griffin PJ, Dowson A, Brewer DS, Gant N, et al. Influence of cold-water immersion on indices of muscle damage following prolonged intermittent shuttle running. J Sports Sci. 2007;25(11):1163-70

16. Jakeman JR, Macrae R, Eston R. A single 10-min bout of cold-water immersion therapy after strenuous plyometric exercise has no beneficial effect on recovery from the symptoms of exercise-induced muscle damage. Ergonomics. 2009;52(4):456-60

17. Getto CN, Golden G. Comparison of active recovery in water and cold-water immersion after exhaustive exercise. Athl Train Sports Health Care. 2013.

18. Elias GP, Wyckelsma VL, Varley MC, McKenna MJ, Aughey RJ. Effectiveness of water immersion on postmatch recovery in elite professional footballers. Int J Sports Physiol Perform. 2013;8(3):243-53.

19. Broatch JR, Petersen A, Bishop DJ. Postexercise cold water immersion benefits are not greater than the placebo effect. Med Sci Sports Exerc. 2014;46(11):2139-47.

20. Demirhan B, Yaman M, Cengiz A, Saritas N, Günay M. Comparison of Ice Massage versus Cold-Water Immersion on Muscle Damage and DOMS Levels of Elite Wrestlers. J Anthropologist. 2015;19(1):123-9.

21. Gil AW, Oliveira MR, Coelho VA, Carvalho CE, Teixeira DC, Silva Jr RA. Relationship between force platform and two functional tests for measuring balance in the elderly. Rev Bras Fisioter. 2011;15(6):429-35.

22. Tano SS, Fernandes KB, Moser AD, Pires-Oliveira DA, Gil AW, Oliveira RF. Effects of cold water immersion on variables of balance in healthy subjects with open and closed eyes. Fisioter Mov. 2015;28(3):467-75.

23. Thain PK, Bleakley CM, Mitchell AC. Muscle reaction time during a simulated lateral ankle sprain after wet-ice application or cold-water immersion. J Athl Train. 2015;50(7):697-703. 